\title{
Recent studies on hydrothermal systems in China: a review
}

\author{
Yanlong Kong ${ }^{1,2^{*}}$, Zhonghe Pang ${ }^{1}$, Haibing Shao ${ }^{2,3}$, Shengbiao Hu${ }^{1}$ and Olaf Kolditz ${ }^{2,4}$
}

\author{
* Correspondence: \\ ylkong@mail.iggcas.ac.cn \\ ${ }^{1}$ Key Laboratory of Shale Gas and \\ Geoengineering, Institute of \\ Geology and Geophysics, Chinese \\ Academy of Sciences, Beijing \\ 100029, China \\ ${ }^{2}$ Department of Environmental \\ Informatics, Helmholtz Centre for \\ Environmental Research - UFZ, \\ Leipzig, Germany \\ Full list of author information is \\ available at the end of the article
}

\begin{abstract}
This paper reviews the state-of-the-art in hydrothermal systems in China with emphasis on current studies of potential and reservoir engineering. Three hydrothermal systems, namely, Yangbajing, Xianyang, and Xiongxian, are used as case studies to represent high temperature granite reservoirs, medium-to-low temperature sandstone reservoirs, and medium-to-low temperature carbonate reservoirs, respectively. There is a huge potential of hydrothermal resources in China that have not been fully studied for possible exploitation. The study reveals that the potential of developing hydrothermal resources is preferable to exploitation of hot-dry-rock (HDR) systems in the near future. In order to enhance the utilization efficiency and prolong the economic lifetime of a geothermal field, reinjection needs to be increased, including treated wastewater as an option. In this regard, deep karstic aquifers containing hot water are the most ideal targets for development due to their favorable characteristics including high single-well yield, low salinity, easy reinjection, and fewer environmental impacts when exploited. The next challenge lies in the geothermal reservoir management for sustainable production. Numerical models describing the full complexity of coupled physicochemical thermodynamic processes such as the open source OpenGeoSys modeling platform are powerful tools for production planning as well as for assessing the possible environmental impacts. Comprehensive reservoir simulation should be employed to provide an optimal fluid production scheme and to maximize the sustainability in the development of a hydrothermal field.
\end{abstract}

Keywords: Hydrothermal systems; Geothermal energy in China; Reinjection technology; Reservoir engineering; OpenGeoSys

\section{Review}

Geothermal energy is a low-carbon energy source. Different from photovoltaic and wind power, it can serve as a base load for the power grid. The geothermal energy can be utilized in three different approaches: 1) the use of heat in shallow groundwater and soil via heat pumps (Shim and Park 2013); 2) heat extracted from hydrothermal reservoirs (Wang et al. 1981); 3) creation of artificially enhanced fracture networks and heat extraction from hot-dry-rock formations, also known as the Enhanced Geothermal Systems (EGS) (Huenges 2010; Breede et al. 2013). In China, the hydrothermal systems are widely distributed and were first utilized in the 1970s for heating and bathing purposes. The hydrothermal resources in the major sedimentary basins of China have been calculated to be around $2.5 \times 10^{22} \mathrm{~J}$, and the amount of exploitable geothermal energy is close to $7.5 \times 10^{21} \mathrm{~J}$. The annual exploitable hydrothermal resources are

\section{Springer}

(c) 2014 Kong et al.; licensee Springer. This is an open access article distributed under the terms of the Creative Commons Attribution License (http://creativecommons.org/licenses/by/4.0), which permits unrestricted use, distribution, and reproduction in any medium, provided the original work is properly credited. 
counted to be $1.8 \times 10^{19} \mathrm{~J}$, which is equivalent to the reduction of 1.4 billion tons of $\mathrm{CO}_{2}$ emission (Wang et al. 2013).

Although geothermal research is mainly motivated by the demand for energy, it also enhances our understanding of the thermal structure of earth's lithosphere and offers new insights into different academic disciplines. It is well known that tectonic activities along plate margins are controlled by thermal processes induced by density contrasts and changes in rheology. Vice versa, the tectonic movements could lead to heat accumulation because of differences in thermal capacities of different strata. Therefore, advances in the research of hydrothermal systems are of significant importance in the understanding of tectonic activities, the formation and distribution of geothermal resources, water-rock interactions, and the concentration of ore-forming elements (Wang et al. 1981). Besides the study of tectonics, the heat anomaly in the hydrothermal reservoir might be a result of groundwater movement. In a high temperature and high pressure environment, the coupled effect of water and heat serves as the driving forces of groundwater flow. It further dominates the dynamics of deep hydrothermal circulations (Balling et al. 2013; Nield and Bejan 2013; Yang et al. 2013). A detailed analysis on hydrothermal systems will advance our understanding on the deep hydrogeological processes, which has wide impact in the fields of geological engineering, environmental impact assessment, and natural hazards protection.

In China, there have been two waves of enthusiasm in the research and development of geothermal energy, which have greatly advanced our understanding on hydrothermal systems. The first one started in the 1970s, when the world was facing the first oil crisis. A great amount of sites were explored and investigated for geothermal energy. This led to nationwide heat flow measurements and later on the compilation of the heat flow map of China (Hu et al. 2000; Wang et al., 2012). After decades of work, the geothermal background and the distribution of main geothermal resources in China have become clear. Meanwhile, research on the genesis of hydrothermal systems has made significant progress with the application and development of new methods. For instance, an approach of thermometry named FixAl was developed to better predict the equilibrium or reservoir temperature (Pang and Reed, 1998). The second wave started in the early 2000s, driven by the demand for clean and renewable energy resources. Today, it is still being fostered by high oil prices and tight control of coal-burning boilers. In August 2012, the National Energy Board released 'the 12th Five-Year Plan'. It set a target on the total development and utilization capacity of geothermal resources to be $15 \mathrm{Mt}$ standard coal $\left(0.4 \times 10^{18} \mathrm{~J}\right)$ by 2015 (Zhao and Wan 2014). The current research efforts focus on the sustainable development of large-scale geothermal fields. In order to help carry out large-scale geothermal resources exploitation, Pang et al. (2015) presented a new classification of geothermal resources based on the type of heat source and followed by the mechanisms of heat transfer. According to this method of classification, geothermal systems in China can be classified into four types: 1) crustal magmatism/ partial crustal melting, 2) dominant radiogenic heat contribution, 3) pure mantle upwelling, 4) with recent volcanic activities; each type can be subclassified into two categories according to their heat transfer mechanism: 1) conduction type; 2) convection type.

In the literature, several researchers have conducted reviews on the geothermal energy in China. Pang et al. (2012) designed a roadmap of geothermal energy development in China and reported the recent progress in geothermal research in China (Pang 
et al. 2014a). Huang et al. (2012) placed their emphasis on the study of geothermal systems related to Cenozoic volcanic activities. Feng et al. (2014) reviewed the enhanced geothermal system. Zhao and Wan (2014) evaluated the current situation of China's geothermal resources from an industrial and economic point of view.

For many geothermal utilization projects in China, a major challenge is the quick drop of the water table. The general public is thus concerned about the handling of land subsidence and water contamination, and decision-makers are questioning the sustainability of hydrothermal systems. Here in this paper, we will present the status of hydrothermal research in China with several case studies and try to address the above issues with constructive recommendations.

\section{Heat flow and geothermal background in China}

A heat flow map can provide a basis on the identification of heat anomaly for geothermal exploration as well as the understanding on earth dynamics and deep geological processes. The heat flow pattern in China can be illustrated by the heat flow map of Figure 1. This map is compiled based on 921 observations sites. It is based on the version of $\mathrm{Hu}$ et al. (2000), with additional data from Sichuan, Jianghan, Tarim, and Bohai Bay basins (Wang et al. 2012). The overall heat flow pattern exhibits high values in the southwest, lower ones in the east and the center, and the lowest in the northwest parts of the country. At the continental scale, the dominant factor on the heat flow pattern appears to be the Meso-Cenozoic tectonic-thermal evolution of the lithosphere. In

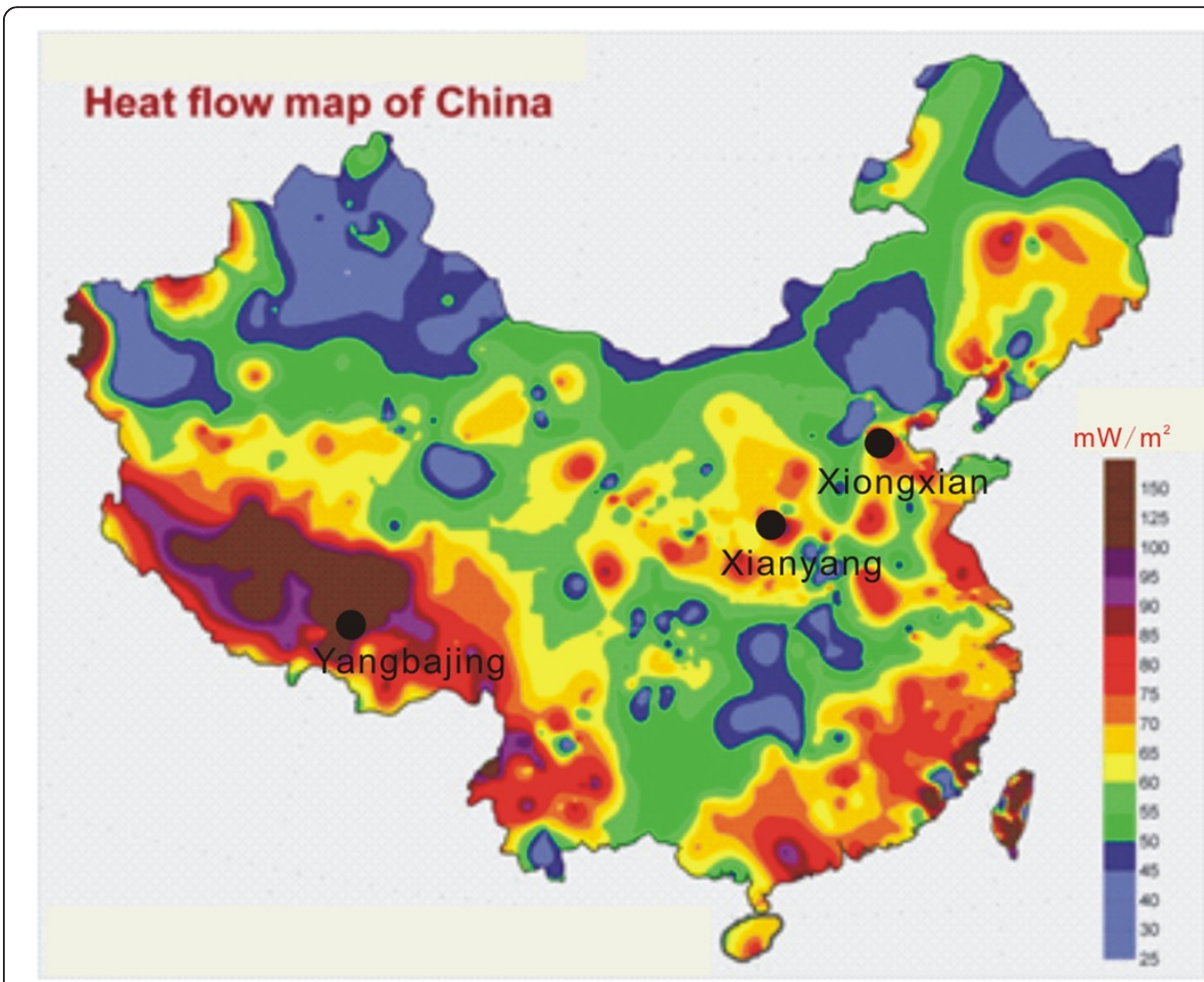

Figure 1 Heat flow map in the continental area of China (revised from Wang et al. 2012). 
regional sedimentary basins, groundwater movement plays an important role (Wang et al. 2012).

\section{Types and occurrence of hydrothermal systems}

Traditionally, the hydrothermal systems only refer to the flow and heat transport processes that redistribute energy and mass in response to circulating fluids such as groundwater and brines (Norton 1984). When the geothermal exploration is taken into account, the study of hydrothermal systems also includes the cost-effective extraction of heat and the industrial process under which it will be processed as well (Ledru and Frottier 2010). In this paper, we focus on the geological aspects of hydrothermal systems, i.e. genesis and exploitation of heat and the hydrothermal aspects through the process of reinjection (see Figure 2), while no attempt is made to review the corresponding economics and industrial processes.

Figure 2 illustrates our conceptual model of the hydrothermal systems. The groundwater in our model is mostly derived from meteoric sources, which is supported by stable isotope and rare gases studies (Truesdell and Hulston 1979; Pang 2011). Such water gradually infiltrates into the ground and is then driven by topographic relief or gravity force to move through the deep strata. Groundwater in the deep aquifers is then heated by surrounding hot rocks or mixed with uprising connate or magmatic fluids through transmissible pores and fractures. Depending on the temperature or salinity, buoyancy effects, together with the compression and thrusting of strata, may drive the flow of groundwater (Cherubini et al. 2013; Tsang and Niemi 2013). Artificial discharge and recharge further alter the pattern of groundwater flow. In this way, topography, heat source, permeability, heterogeneity, and hydraulic anisotropy of the aquifer types can all be the controlling factors of the flow patterns (Garven 1995).

Hydrothermal systems are widely distributed throughout China (Figure 3). Consistent to the spatial distribution of heat flow (Figure 1), a high temperature $\left(>150^{\circ} \mathrm{C}\right)$ geothermal zone is mainly found in the southwest of China, and middle $\left(90^{\circ} \mathrm{C}\right.$ to $\left.150^{\circ} \mathrm{C}\right)$ to low

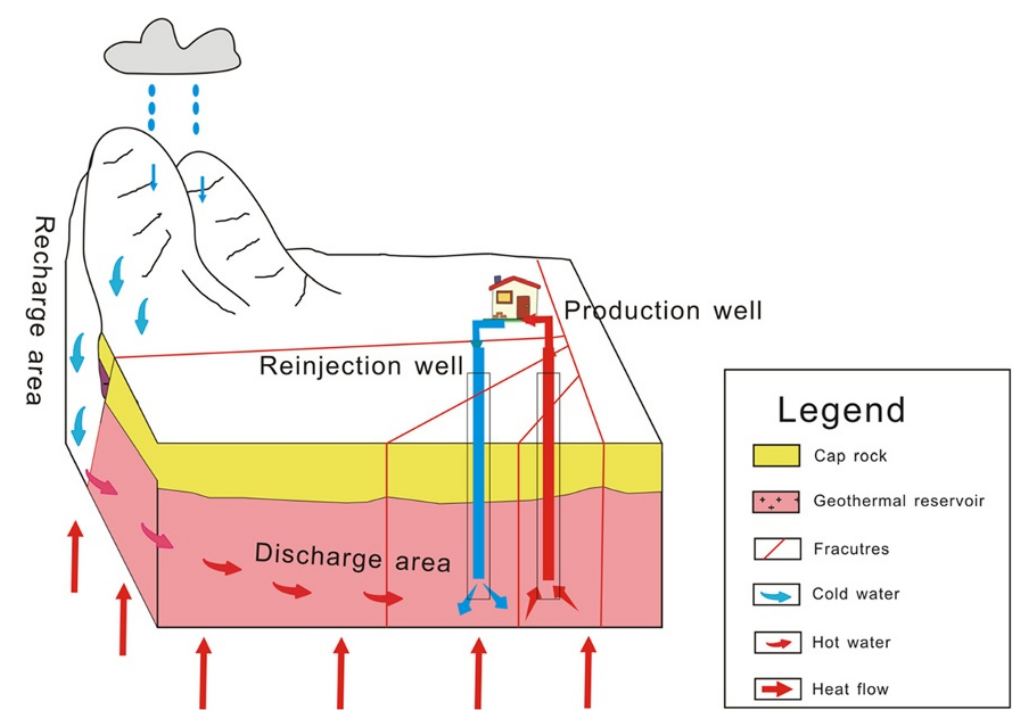

Figure 2 The conceptual model of reservoir engineering in the hydrothermal systems. 


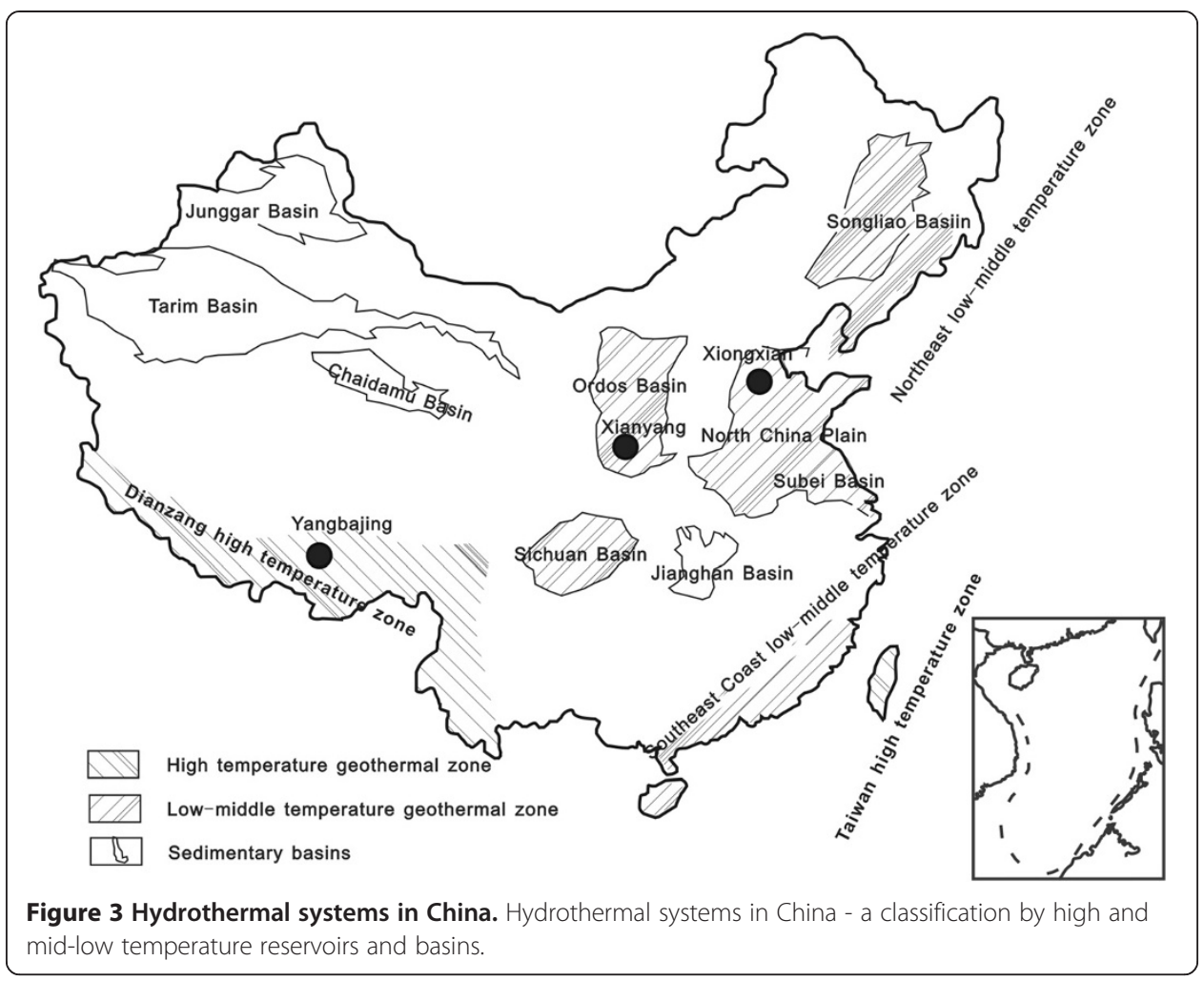

$\left(<90^{\circ} \mathrm{C}\right)$ temperature geothermal resources are widely spread in east and central China (Figure 3). The hydrothermal activity in the Dianzang (also known as Yunnan-Tibet) high temperature geothermal zone in the southwest of China is largely driven by the collision of the Indian and Eurasian plates. The other high temperature zone is located in the Taiwan island, which sits on a Cenozoic tectonically active zone. Besides the high temperature systems, there are many Meso-Cenozoic sedimentary basins with widespread aquifers, containing middle-to-low temperature geothermal resources (Figure 3). These reservoirs can be further categorized based on their rock types. The high temperature field in Yangbajing derives from the granite reservoir on the Tibet plateau. The middle-to-low temperature sites of Xiongxian (North China Plain) and Xianyang (Guanzhong basin) consist of limestone and sandstone formations, respectively. We select them as case study sites and present the details in the following text.

\section{Yangbajing (Tibetan Plateau)}

The Yangbajing geothermal field is located $94 \mathrm{~km}$ to the northwest of Lhasa, the capital of the Tibet Autonomous Region of China, at elevations ranging from 4,290 to $4,450 \mathrm{~m}$. It is a high temperature geothermal field at the eastern extension of the Mediterranean-Himalayan geothermal belt. The convective system of Yangbajing geothermal field consists of shallow and deep reservoirs. The shallow reservoir is in unconsolidated Quaternary alluvium and altered Himalayan granite, with temperatures ranging from $150^{\circ} \mathrm{C}$ to $165^{\circ} \mathrm{C}$ at a depth ranging from 180 to $280 \mathrm{~m}$. The deep reservoir is composed of two parts: one with a temperature of $251^{\circ} \mathrm{C}$ at depths from 950 to $1,350 \mathrm{~m}$ and the other part below a depth of $1,850 \mathrm{~m}$ with temperatures up to $329^{\circ} \mathrm{C}$. 
The Yangbajing field is in an active part of a large-scale slip-fault zone of a metamorphic core complex, which is caused by tensional graben and Proterozoic strata detachment and emplacement. A high temperature magma body underneath the deep reservoir is thought to be the heat source (Dorji and Zhao 2000). Meteoric water is heated along its seepage through tensional fractures and fissures of the core complex. Hydro-geochemical data show that the groundwater in the shallow reservoir is a mixture of cold water and hot water from the deep reservoir (Dorji and Zhao 2000; Guo et al. 2007).

The utilization of geothermal energy in Yangbajing geothermal field includes electric power generation, greenhouse planting, bathing, and space heating, etc. The Yangbajing power plant was built in 1977 and has an installed capacity of $25.18 \mathrm{MW}$ since 1987. It is the only high temperature geothermal power plant in China. In the 1980s, the power from this geothermal field accounted for $41.5 \%$ of the total annual electricity consumption of Lhasa city. As the reinjection was not performed in this field, the hydraulic head in the shallow reservoir declined sharply along with the fluid extraction over the past years. As a result, the deep reservoir has begun to be exploited to support power generation.

\section{Xianyang (Guanzhong basin)}

Xianyang geothermal field lies in the center of Shaanxi Province. It is about $25 \mathrm{~km}$ northwest of Xi'an, the capital of the province. The reservoir is located in the Wei River sedimentary basin, as part of the Guanzhong basin. It is a symmetrical half graben basin, tilted from north to south. The Wei River basin is bounded by the steep Qinling Mountains in the south and the North Mountains from the northern side. Different from the Xiongxian field (Section 3.3), the Xianyang reservoir is composed of poroustype sandstone formation. This formation can be further divided into four stratifications, including the Sanmen, Zhangjiapo, Lantianbahe, and Gaoling layers. The thinner crust and lower depth of Moho boundary (with a depth of 30 to $32 \mathrm{~km}$ ) enhances the heat conduction process, leading to a high heat flux of about $70 \mathrm{~mW} / \mathrm{m}^{2}$ in the vicinity of the reservoir. Additionally, various faults and fractures in this field provide pathways for high temperature groundwater. The recharging source of the field is from precipitation in the southern mountains (Pang et al. 2014b).

Since the first geothermal well drilled in 1993, over 40 geothermal wells have been drilled in the region, with a depth ranging from 1,464 to $4,080 \mathrm{~m}$. The recorded reservoir temperatures are between $55^{\circ} \mathrm{C}$ to $120^{\circ} \mathrm{C}$. New geothermal boreholes drilled in the past few years reached greater depths and are mostly at 3,000 $\mathrm{m}$ or beyond, and directional drilling techniques have also been applied in the region. Similar to Xiongxian (Section 3.3), geothermal fluid produced from the reservoir is utilized for space heating in the urban area of Xianyang. These wells only operate every year from November 15th to March 15th the following year. In Xianyang, reinjection into sandstone formation is performed at an experimental scale, being aware of the risk of clogging the reservoir formation, or the reinjection well itself (Ungemach 2003; Erlingsson et al. 2010). Several reinjection wells have been constructed and tracer tests are being carried out to obtain more information of the reservoir formation. Large-scale reinjection is planned for the near future. 


\section{Xiongxian (Bohai Bay basin)}

The Xiongxian geothermal field is located on the North China Plain, about $100 \mathrm{~km}$ to the south of Beijing. It has a total area of around $320 \mathrm{~km}^{2}$. Based on the vertical temperature profile and rock properties measured in the field, Liu et al. (2015) estimated the total amount of heat in the Xiongxian geothermal field to be $35.8 \pm$ $8.3 \times 10^{16} \mathrm{~kJ}$. Geologically, the reservoir is part of the Niutuozhen uplift in the Bohai Bay basin. It is composed of mid-temperature karstic bedrock with a large amount of fractures, allowing heat transfer in both convective and conductive forms (Zhou et al. 1989). Geochemical and isotopic investigation shows that the reservoir groundwater comes from two different sources. During the cooler climate in the late Pleistocene period $\left(6^{\circ} \mathrm{C}\right.$ to $9^{\circ} \mathrm{C}$ cooler than temperature of the present, (Chen et al. 2003)), precipitated water in the Taihang and Yanshan Mountains infiltrated through the sags and uplift to its north and west and was turned into regional recharge (Kong et al. 2015). Another source of recharge is the heated uprising saline water from the deep Niudong fault. The limestone reservoir is covered by a Neogene sandstone layer with a thickness of 500 to $600 \mathrm{~m}$ and a Quaternary clay layer with a thickness of 400 to $500 \mathrm{~m}$. These two layers form an assemblage and serve as perfect cap rocks for the reservoir.

Geothermal water in Xiongxian has been used for more than 30 years, with reservoir temperatures ranging from $50^{\circ} \mathrm{C}$ to $95^{\circ} \mathrm{C}$. Before 2009 , the geothermal energy was exploited by local residents and industries for space heating, bathing, and greenhouse agriculture. The majority of these wells have operated without reinjection procedures, causing a 30-m drop of the groundwater table from 2001 to 2009. In 2009, China Petroleum \& Chemical Corporation (Sinopec) made an investment in the reservoir, with the construction of 27 new production/reinjection wells, and a refurbishment of 15 existing wells. As recommended by the modeling result (Pang et al. 2014b), reinjection wells are constructed away from the production wells, in order to optimize the utilization efficiency and prevent preferential flows. All 42 wells are then connected to a central heating system and provide heat for the entire Xiongxian city from Nov 15th to March 15th every year. During the operation, the extracted reservoir water flows through multiple heat exchangers, with an average inflow temperature of $68^{\circ} \mathrm{C}$ and a reinjection temperature around $35^{\circ} \mathrm{C}$. A $100 \%$ reinjection ratio is achieved in the Xiongxian city. As a result, groundwater level has to recover, though slowly.

\section{Discussion}

From the research and development of hydrothermal systems during the past decades, we notice several common issues in the development of hydrothermal energy in China.

First of all, there is a huge potential for employing hydrothermal systems in China as a renewable energy resource, which can be seen from Figure 4. The total geothermal energy in these basins is $2.5 \times 10^{22} \mathrm{~J}$ (Wang et al., 2013), which is about 260 times of total China energy consumption in $2010\left(95.2 \times 10^{18} \mathrm{~J}\right)$. The utilization of hydrothermal resources is undergoing a rapid development, and strong growth can be further expected. Figure 5 shows an impressive growth of the direct usage of hydrothermal energy in China over the past years. Together with the maturity of exploration technologies, a turning point has been triggered in 2010, also facilitated by policy encouragement of government in the form of tax breaks and subsidies. In recent years, large amounts of new projects 


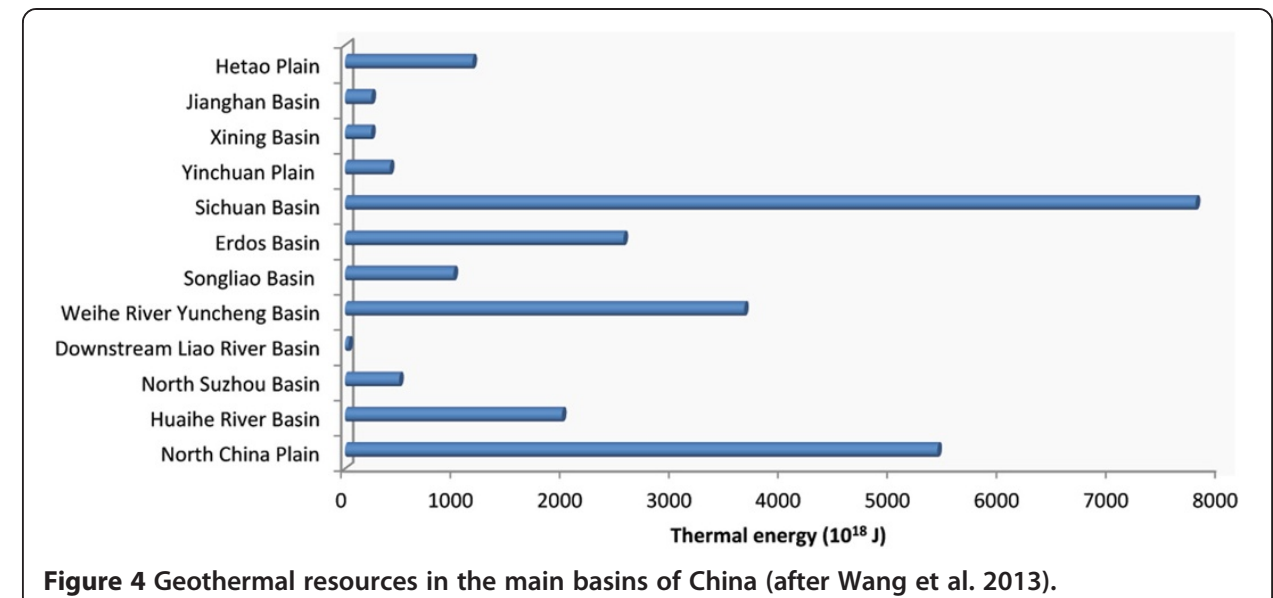

have been proposed all over China. Especially in the North China Plain, Subei basin, Sichuan basin, and Tibetan Plateau, construction of new hydrothermal fields has been welcomed and promoted by the local authorities. Thus, it is reasonable to believe that the installed capacity will easily achieve the strategic target in 2050, which is made on the basis of geothermal exploitation and development by Working Group on Middle to Long Term Development Strategy of Energy in China (2011).

Regarding the strategy of geothermal energy utilization in China, the utilization of hydrothermal systems should be prior to EGS in the near future. Firstly, there is still a huge potential of hydrothermal systems that has not been fully exploited. The annual direct use of geothermal energy (including heat pumps) in China is about $7.5 \times 10^{13} \mathrm{~J}$ (Lund et al. 2011), which is far less than the total hydrothermal energy of $2.5 \times 10^{22} \mathrm{~J}$. Secondly, the Enhanced Geothermal Systems (EGS) are still in the experimental and pilot stage (Liao et al. 2014; Pang et al. 2014a), which is far from the maturity for commercial use. Thirdly, the cost of hydrothermal utilization is generally under $2 \mathrm{c} / \mathrm{kWh}$

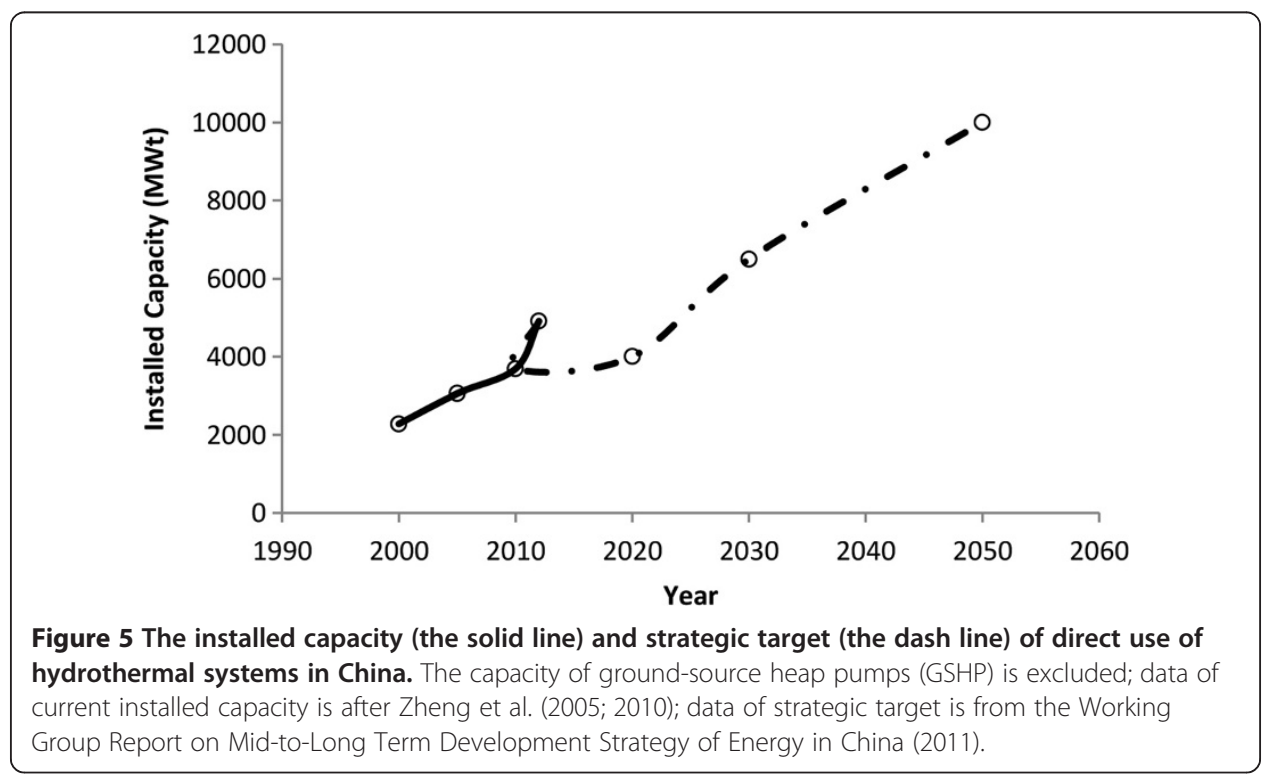


for space heating and $4 \mathrm{\Phi} / \mathrm{kWh}$ for electric generation (Fridleifsson 2001), while the lowest possible cost for the utilization of EGS is $5.43 \mathrm{~d} / \mathrm{kWh}$ (Sanyal et al. 2007).

We also learned from the case studies that reinjection is absolutely essential for the sustainable utilization of hydrothermal systems. The drawdown of groundwater table during exploitation is a limiting factor to the long-term, sustainable application of hydrothermal resources. Taking the Xiongxian field (Section 3.3) as an example, the total hydrothermal resources are about $3.7 \times 10^{20} \mathrm{~J}$, and the annual heat load is only $5.5 \times 10^{7} \mathrm{~J}$. If the thermal water were to be exploited in an unregulated way as in the past 30 years, the resources will be soon depleted (Pang et al. 2014b; Kong et al. 2015). With the centralized management approach applied in Xiongxian and Xianyang, a sustainable operation approach with reinjection leads to the recovery of the water table (Liu and Wang 2006; Duan et al. 2011; Pang et al., 2014b). On the topic of reinjection operation, scientific and technical challenges still remain. For example, the low permeability of sandstone formations and the clogging of reinjection wells often lead to higher costs. Research and development efforts should focus on the geochemical and geomechanical aspects of the reservoir formation (Reinsch et al. 2013). Also, proper planning and distribution of the production/reinjection wells should be presented in order to maintain the reservoir pressure without thermal breakthrough (Axelsson 2010; Kolditz et al. 2013).

To help handle the above challenges, hydro-geochemical approaches and reservoir simulation technology are extremely important for the hydrothermal reservoirs. First, the hydro-geochemical methods are vital to build a conceptual model of a hydrothermal system including identifying the heat source, water source and its flow path, reservoirs, and cap rock. The thermometry techniques on the basis of geochemical data are even useful to identify the target of heat anomaly. For instance, Pang et al. (2011) predicted the reservoir temperature in the Taxian basin, the western Himalayan syntaxis could reach $173^{\circ} \mathrm{C}$ to $191^{\circ} \mathrm{C}$ and concluded the Taxian geothermal system belongs to high temperature convective type, which was finally confirmed by the borehole exploration. Second, the construction of 3D geological models in the site exploration stage will help to identify important factors and processes that determine the field performance. The experiences of using reservoir-modeling technologies in various kinds of geothermal reservoirs (eg. Stralsund, Urach Spa, and KTB in Germany, Rosemanowes in United Kingdom, Soultz-sous-Forêts in France, and Taupo Volcanic Zone in New Zealand) show that the location and opening of production/reinjection wells will change the deep fluid and heat transfer, which is directly relevant to the exploitation of geothermal energy (Kolditz and Clauser 1998; Kisssling and Weir 2005; McDermott and Kolditz 2006; Tenzer et al. 2010). Third, the modeling of local and regional groundwater circulation helps to predict the flow and heat transport process in the reservoir. Advanced modeling tools can also allow the optimization of production/reinfiltration operations. Fourth, for the long-term behavior of the reservoir, and for obtaining the maximum amount of energy resources in the context of sustainable utilization, particular emphasis has to be placed on geochemical alternations, thermomechanical and hydromechanical effects as well as their effects on reservoir evolution (Kolditz et al. 2012). This requires coupled thermal-hydraulic-mechanical-chemical (THMC) modeling tools such as the open source OpenGeoSys modeling platform to work on the basis of new in situ experiments and observations on THMC processes in hydrothermal 
systems at both local and regional scale. By now, there are few geothermal exploration cases where the multi-field, multi-phase modeling techniques have been applied in China. Therefore, modern reservoir simulation tools have high potential in the exploration and utilization of hydrothermal systems (Huenges et al. 2013).

\section{Conclusions}

The presented study summarizes the progress and current status of hydrothermal research in China. Great progress has been made in the research to help the development of heat extraction from hydrothermal systems over the past decades. Conceptual model of hydrothermal systems with three cases of Yangbajing (high temperature granite reservoir), Xianyang (middle-to-low temperature sandstone reservoir), and Xiongxian (middle-tolow temperature karstic reservoir) are elaborated. Our research highlights the potential of hydrothermal resources that has not been fully exploited in China and should encourage continuing scientific research and technology development as well as political support for a sustainable utilization of geothermal resources as a renewable energy source to substitute fossil fuel in view of their severe environmental impacts.

Several recommendations are presented:

(1) The exploitation and development of hydrothermal systems take priority over that of hot-dry rock in the near future.

(2) Emphasis should be placed on large-scale hydrothermal field exploitation (especially deep karstic reservoirs) and the study on their potential environmental impacts.

(3) Reservoir management through regarding with reinjection should be attached importance to and THMC modeling technologies should be employed to improve reservoir modeling in order to achieve the sustainable exploitation of hydrothermal systems.

Competing interests

The authors declare that they have no competing interests.

Authors' contributions

All: Systematic review of recent studies of hydrothermal systems in China. YK and HS: prepare the manuscript; ZP and OK: revise and improve the manuscript; SH: Figure 1; YK: Figure 2, 3, 4, 5. All authors read and approved the final manuscript.

\section{Acknowledgements}

This study is supported by the National Natural Science Foundation of China (grant 41372257). The authors appreciate the International Postdoctoral Exchange Fellowship Program China (20130019) and Project funded by China Postdoctoral Science Foundation (2013 M540138) for the financial support of this work. The support for the research stay of Dr. Kong with the Helmholtz Centre for Environmental Research, Department of Environmental Informatics, by the Helmholtz Association under the 'Renewable Energy Program' is greatly acknowledged. The authors wish to thank two anonymous reviewers for their constructive comments and Ms. Leslie Jakobs MA for improving the use of English in the manuscript.

\section{Author details}

${ }^{1}$ Key Laboratory of Shale Gas and Geoengineering, Institute of Geology and Geophysics, Chinese Academy of Sciences, Beijing 100029, China. ${ }^{2}$ Department of Environmental Informatics, Helmholtz Centre for Environmental Research - UFZ, Leipzig, Germany. ${ }^{3}$ Geothermal Systems Analysis, Freiberg University of Mining and Technology, Freiberg, Germany.

${ }^{4}$ Applied Environmental Systems Analysis, Dresden University of Technology, Dresden, Germany.

Received: 21 August 2014 Accepted: 25 November 2014

Published online: 23 December 2014

References

Axelsson G (2010) Sustainable geothermal utilization - case histories; definitions; research issues and modelling. Geothermics 39:283-291

Balling P, Maystrenko Y, Scheck-Wenderoth M (2013) The deep thermal field of the Glueckstadt Graben. Environ Earth Sci 70:3505-3522 
Breede K, Dzebisashvili K, Liu X, Falcone G (2013) A systematic review of enhanced (or engineered) geothermal systems: past, present and future. Geotherm Energ 1:4

Chen Z, Qi J, Xu J, Xu J, Ye H, Nan Y (2003) Paleoclimatic interpretation of the past 30,000 yr from isotopic studies of the deep confined aquifer of the North China Plain. Appl Geochem 18:997-1009

Cherubini Y, Cacace M, Scheck-Wenderoth M, Moeck I, Lewerenz B (2013) Controls on the deep thermal field: implications from 3-D numerical simulations for the geothermal research site Gro Schonebeck. Environ Earth Sci 70:3619-1642

Dordi, Zhao P (2000) Characteristics and genesis of the Yangbajing geothermal field, Tibet, Proceedings World Geothermal Congress 2000, Kyushu - Tohoku, Japan, May 28 - June 10

Duan Z, Pang Z, Wang X (2011) Sustainable evaluation of limestone geothermal reservoirs with extended production histories in Beijing and Tianjin, China. Geothermics 40:125-135

Erlingsson T, Jóhannesson T, Olafsson E, Axelsson G (2010) Geothermal district heating system in XianYang, Shaanxi, China, Proceedings World Geothermal Congress 2010, Bali, Indonesia, 25-29, April 2010

Feng Y, Chen X, Xu X (2014) Current status and potentials of enhanced geothermal system in China: a review. Renew Sustain Energy Rev 33:214-223

Fridleifsson I (2001) Geothermal energy for the benefit of the people. Renew Sustain Energy Rev 5:299-312

Garven G (1995) Continental-scale groundwater flow and geologic processes. Annu Rev Earth Planet Sci 23:89-117

Guo Q, Wang Y, Liu W (2007) Major hydrogeochemical processes in the two reservoirs of the Yangbajing geothermal field, Tibet, China. J Volcanol Geotherm Res 3-4:255-268

Hu S, He L, Wang J (2000) Heat flow in the continental area of China: a new data set. Earth Planet Sci Lett 179:407-419

Huang S (2012) Geothermal energy in China. Nat Clim Chang 8:557-560

Huenges E (ed) (2010) Geothermal energy systems: exploration, development, and utilization. Wiley-VCH, Berlin

Huenges E, Kohl T, Kolditz O, Bremer J, Scheck-Wenderoth M, Vienken T (2013) Geothermal energy system: research perspective for domestic energy provision, Environ. Earth Sci 70(8):3927-3933

Kisssling W, Weir G (2005) The spatial distribution of the geothermal fields in the Taupo Volcanic Zone, New Zealand. J Volcanol Geotherm Res 145:136-150

Kolditz O, Bauer S, Bilke L, Bottcher N, Delfs JO, Fischer T, Gorke UJ, Kalbacher T, Kosakowski G, McDermott Cl, Park CH, Radu F, Rink K, Shao H, Shao HB, Sun F, Sun YY, Singh AK, Taron J, Walther M, Wang W, Watanabe N, Wu N, Xie M, Xu W, Zehner B (2012) OpenGeoSys: an open-source initiative for numerical simulation of thermo-hydro-mechanical/ chemical (THM/C) processes in porous media. Environ Earth Sci 67(2):589-599. doi:10.1007/s12665-012-1546-X

Kolditz O, Clauser C (1998) Numerical simulation of flow and heat transfer in fractured crystalline rocks: application to the hot dry rock site at Rosemanowes (UK)). Geothermics 28(1):1-26

Kolditz O, Jakobs LA, Huenges E, Kohl T (2013) Geotherm Energ 1:1, doi:10.1186/2195-9706-1-1

Kong Y, Pang Z, Pang J, Luo L, Luo J, Shao H, Kolditz O (2015) Deep groundwater cycle in Xiongxian geothermal field, Proceedings World Geothermal Congress 2015, Melbourne, Australia, April, 19-25

Ledru P, Frottier L (2010) Reservoir Definition, in (Huenges, E ed.) Geothermal Energy Systems, Exploration, Development, and Utilization, 1 - 36, Wiley-VCH, Berlin

Liao Z, Wan T, Zhang Z (2014) The enhanced geothermal system (EGS): huge capacity and difficult of exploitation. Earth Sci Front 2014(21):1-10

Liu J, Wang K (2006) Geothermal reinjection in China. Proceedings of the 7th Asian Geothermal Symposium, July, 25-26.

Liu S, Liu J, Yang F, Pang Z, Zhou D (2015) Combined Monte Carlo simulation and geological modeling for geothermal resource assessment: a case study of Xiongxian geothermal field, China, Proceedings World Geothermal Congress (2015). Melbourne, Australia (in press)

Lund J, Freeston D, Boyd T (2011) Direct utilization of geothermal energy 2010 worldwide review. Geothermics 40:159-180

McDermott C, Kolditz O (2006) Geomechanical model for fracture deformation under hydraulic, mechanical and thermal loads. Hydrogeol J 14(4):485-498

Nield D, Bejan A (2013) Convection in porous media. Springer, New York, p 778

Norton D (1984) Theory of hydrothermal systems. Ann Rev Earth Planet Sci 12:155-177

Pang Z (2011) Isotopes in the geothermal water. In: Gu W (ed) Isotope hydrology. Science Press, Beijing

Pang Z, Hu S, Wang J (2012) A roadmap to geothermal energy in China. Sci Technol Rev 30(32):18-24

Pang Z, Huang S, Hu S, Zhao P, He L (2014a) Geothermal studies in China: progress and prospects 1995-2014. Chin J Geol 49:719-727

Pang Z, Kong Y, Luo L, Yang F, Duan Z, Pang J, Luo J (2014b) Research on the classification, formation mechanism and reservoir evaluation of typical geothermal systems in China, report to SINOPEC., pp 1-243

Pang Z, Luo J, Pang J (2015) Towards a New classification scheme of geothermal systems in China. Proceedings World Geothermal Congress 2015, Melbourne, Australia, April, 19-25

Pang Z, Reed M (1998) Theoretical chemical thermometry on geothermal waters: problems and methods. Geochim Cosmochim Acta 62:1083-1091

Pang Z, Yang F, Yuan L, Li Y (2011) Geothermal manifestation and reservoir temperature prediction in Taxian basin, Xinjiang. Geol Rev 57:86-88

Reinsch T, Henninges J, Asmundsson R (2013) Thermal, mechanical and chemical influences on the performance of optical fibres for distributed temperature sensing in a hot geothermal well. Environ Earth Sci 70:3465-3480

Sanyal S, Morrow J, Butler S, Robertson-Tait A (2007) Cost of electricity from enhanced geothermal systems. Proceedings, thirty-second workshop on geothermal reservoir engineering, Stanford University, Stanford, California, January 22-24, 2007

Shim B, Park C (2013) Ground thermal conductivity for (ground source heat pumps) GSHPs in Korea. Energy 56:167-174

Tenzer H, Park CH, Kolditz O, McDermott Cl (2010) Application of the geomechanical facies approach and comparison of exploration and evaluation methods used at Soultz-sous-Forêts (France) and Spa Urach (Germany) geothermal sites. Environ Earth Sci 61(4):853-880

Truesdell A, Hulston J (1979) Isotopic evidence on environments of geothermal waters. In: Fritz P, Fontes JC (eds) Handbook of environmental isotope geochemistry, vol 1. Elsevier, Amsterdam, pp 179-226

Tsang C, Niemi A (2013) Deep hydrogeology: a discussion of issues and research needs. Hydrogeol J 21:1687-1690 
Ungemach P (2003) Reinjection of cooled geothermal brines into sandstone reservoirs. Geothermics 4-6:743-76 Wang G, Li K, Wen D, Lin W, Lin L, Liu Z, Zhang W, Ma F, Wang W (2013) Assessment of geothermal resources in China, Proceedings, Thirty - Eighth Workshop on Geothermal Reservoir Engineering, Stanford University, Stanford, California, Febuary $11-13$

Wang J, Chen M, Wang J, Deng D, Wang J, Shen HC, Hsiung LP, Yan S, Fan Z, Liu X, Huang G, Zhang W, Shao H, Zhang Y (1981) Geothermal studies in China. J Volcanol Geotherm Res 9:57-76

Wang J, Hu S, Pang Z, He L, Zhao P, Zhu C, Rao S, Tang X, Kong Y, Luo L, Li W (2012) Estimate of geothermal resources potential for hot dry rock in the continental area of China. Sci Technol Rev 30(32):25-31

Working Group on Middle to Long Term Development Strategy of Energy in China (2011) The Mid and long term (2030, 2050) development strategy of energy in China, renewable energy. Science Press, Beijing

Yang F, Pang Z, Lin L, Jia Z, Zhang F, Duan Z, Zong Z (2013) Hydrogeochemical and isotopic evidence for trans-formational flow in a sedimentary basin: Implications for CO2 storage. Appl Geochem 30:4-15

Zhao X, Wan G (2014) Current situation and prospect of China's geothermal resources, Renewable \& Sustainable Energy Reviews, 32 , : $651-661$.

Zheng K, Han Z, Zhang Z (2010) Steady industrialized development of geothermal energy in China, In: Proceedings of the 2010 World Geothermal Congress, Bali, Indonesia, April 25-29, 2010, paper No. 0136, 11 pp

Zheng K, Zhang Z, Zhu H, Liu S (2005) Process and prospects of industrialized development of geothermal resources in China - country update report for 2000 - 2004, In: Proc. WGC2005

Zhou R, Liu Q, Zhang J, Yang L. (1989) The geological features and exploitive prospects of the geothermal field of saline type of niutuozhen in the fault basin of China, Bulletin of the 562 Comprehensive Geological Bridge Chinese Academy of Geological Sciences, 7-8: 21-35

doi:10.1186/s40517-014-0019-8

Cite this article as: Kong et al:: Recent studies on hydrothermal systems in China: a review. Geothermal Energy 2014 2:19.

Submit your manuscript to a SpringerOpen ${ }^{\mathcal{O}}$ journal and benefit from:

- Convenient online submission

Rigorous peer review

- Immediate publication on acceptance

- Open access: articles freely available online

- High visibility within the field

- Retaining the copyright to your article

Submit your next manuscript at $\boldsymbol{\sim}$ springeropen.com 